\title{
Anatomy of a campaign: the attempt to defeat the New South Wales (Australia) Tobacco Advertising Prohibition Bill 1991
}

\author{
Simon Chapman
}

\begin{abstract}
In late 1991 the Australian tobacco industry launched a massive advertising campaign in an attempt to dissuade politicians in the state of New South Wales from passing the Tobacco Advertising Prohibition Bill 1991, which sought to end all remaining forms of tobacco advertising in New South Wales, including the publicity given to sponsorships of sporting events. Themes and rhetorical devices used to frame the industry's opposition are described. These include lost jobs; hardship for the "little person" during the recession; the "criminalisation" of honest workers; hypocrisy; neopuritanism; freedom to choose; paternalism; the opposition of the public ; and the absence of advertising in Russia. The choice of these themes and attempts to counter them by health workers are discussed.
\end{abstract}

\section{Background}

As a result of national government legislation, direct advertising of cigarettes has been prohibited on Australian radio and television since 1976 and in locally published print media since December 1990. The remaining forms of advertising (cinema, outdoors, sampling, shop fronts, and points of sale) are under the control of each of the six state and two territory governments. In the past five years four of these have legislated to prohibit these remaining forms that fell under their jurisdictions. New South Wales (NSW) is the most populous state and is currently the only state with a conservative (Liberal/National coalition) government in power. Until passage of the New South Wales Tobacco Advertising Prohibition Bill 1991 cigarette advertising outdoors, on the back of taxis, in shop fronts, and at points of sale remained in New South Wales. Massive media coverage also continues to be given to tobacco sponsored events such as the Winfield Rugby League Cup and the international Benson and Hedges cricket series. These two sports dominate (respectively) winter and summer sports coverage in the broadcasting media, regularly topping all other programmes in television audience share ratings. New South Wales has been widely regarded as symbolic of the industry's last stand in Australia and has enjoyed the overt support of the State Premier, who has often publicly trivialised the tobacco control issue, saying recently for example that it was "really very marginal to the wellbeing of mankind."1

In 1991 minor political parties and independent politicians held the balance of power in both the Upper and Lower Houses of Parliament in New South Wales. One such member, the Reverend Fred Nile, introduced the Tobacco Advertising Prohibition Bill 1991, which sought to end all remaining forms of tobacco advertising in New South Wales, including publicity given to sponsorship of sporting events. Nile had the support of the Opposition (Labor) and Democrat Parties. Together, these groups had the numbers to defeat the government, which initially indicated that it was vehemently opposed to the bill. As the date approached for the parliamentary debate, the government, realising the inevitably of defeat, changed its position and introduced exemption amendments (see below) while executing a volte face and declaring that it now supported the overall thrust of the bill to ban all remaining forms of advertising. $^{2}$

When Nile's intentions became public the tobacco industry through its lobby office, the Tobacco Institute, launched a huge press advertising campaign in an attempt to scare political support in all parties away from the bill. (In Australia the tobacco industry is Rothmans, WD and HO Wills (BAT), and Philip Morris.) Sporting groups receiving tobacco sponsorship also supported the industry campaign through lobbying, advertising, and the media announcements. The size and ferocity of the campaign was testimony to the degree of concern the industry felt at the prospects of losing the remainder of its advertising outlets and of a possible boost to an international domino effect. Grand hyperbole frequently ran riot in the advertising with claims, for example, that the politicians behind the ban were "effectively ruining our state and our lives. This is only the start of what he has in mind for us. Books and alcohol are firm favourites!"

Below I describe the principal themes and rhetorical devices used in the industry's campaign. As will be seen, these exhibit several approaches long favoured by the industry in its international lobbying. However, several significant emphases and admissions emerged which will interest all who are concerned to 
keep abreast of the industry's tactics in this field. Given the sheer volume of advertising published, I have extracted examples of the themes under various headings, rather than attempting any exhaustive catalogue of all that was run by the industry and its supporters. My emphases are italicised throughout.

\section{Enough is enough!}

One theme, encapsulated in the repeated headline Enough is Enough!, dominated the campaign. This was shorthand for a complex connotative chain evoking notions of unfairness, bullying, and lack of compassion and of Orwellian government law makers running out of control ("Any politicians who support the Bill are displaying a callous disregard for the welfare of the ordinary people of New South Wales," argued one advertisement.) Akin to the proverbial slippery slope, thin edge of the wedge, or where will it all end rhetoric long favoured by the industry, the slogan sat astride advertisements ranging from cartoons mocking the politicians who supported the bill to testimonial advertising from sponsored sporting groups, allied industries - for example, printing - and "little people" said to be about to suffer at the hand of the bill's provisions. Subthemes under the Enough is Enough! banner included:

\section{Jobs will be lost}

The proposed ban may well have caused some job losses in, for example, advertising agencies, which would have lost tobacco accounts, and in poster hanging companies, which have in recent years benefited greatly from restrictions in other tobacco advertising outlets. However, it would have been difficult for the industry to argue that these losses would number more than 100 in New South Wales. As such, there was about as much capital in arguing for the retention of these jobs as the motor vehicle smash repair industry complaining about lost jobs due to the downturn in road crashes caused by the introduction of random alcohol breath testing (as indeed some newspaper letter writers did argue, tongue in cheek, during the campaign).

Faced with this situation, the industry threw all care to the wind with claims of job losses right across the tobacco spectrum. Despite its usual meticulous insistence that advertising does not influence aggregate demand for cigarettes, any pretence that the proposed ban would not cause a downturn in sales was utterly abandoned in this campaign. The Tobacso Institute claimed that the bill "puts at risk the livelihoods of 25344 other decent Australians who make their living from the tobacco industry in New South Wales. There are growers, manufacturers, shop floor, wholesalers, retailers, drivers, packers, not to mention the printers, shop fitters, painters, outdoor advertising companies and their sales staff." Similar claims were made by the tobacco retailers' trade association, which argued that restrictions even on point of sale advertising threatened to "ultimately result in ... the loss of another 25000 jobs in the long term... hundreds of resellers [retailers] will eventually go out of business." The printing industry, which prints advertising signs and cigarette packs, claimed, "if this is done in New South Wales, jobs will be lost - and some printing companies will be forced to close their doors because of the millions of dollars of revenue that is at risk in our industry alone."

The logic of these claims bordered on the asinine with ambidextrous claims like the bill would "reduce the number of jobs in this State rather than the incidence of smoking" and "Banning advertising won't stop people smoking. But the minority think differently. They want us to sacrifice jobs, funds for sport, and the arts, for an idea which doesn't work. Don't let their minority opinions overthrow plain commonsense." Here it can be seen that commonsense to the industry means the ability to totally contradict oneself within the one sentence: if advertising bans won't reduce smoking, how is it that jobs could be lost?

Hardship for the little person during the recession

Several advertisements featured small business people who would allegedly suffer financial hardship if the advertising ban was enacted. Advertisements entitled Don't kick us while we're down featured testimonials from an outdoor poster hanger: "I wish the politicians would listen to the little people before they start bringing in new bills! I reckon contractors stand to lose roughly $\$ 500$ a week if the AntiTobacco Bill goes through... The tobacco companies spend millions on outdoor advertising. You simply can't take that much out of an industry and not lose jobs! It's no use saying other people will take the space... So here we go again. The little guys cop it in the neck and politicians wonder why voters are looking for alternatives."

Despite this poster hanger claiming that alternative poster advertisers would not be available to replace the lost tobacco advertising, in the very same advertisement, in the very next testimonial, a taxi fleet manager seemed to know differently. Speaking of the revenue he got from tobacco advertising on the back of his taxis ("It's used to pay my mortgage and general bills"), he said, "Believe me in this recession it's not easy to get advertisers... The big advertisers will be busy taking over the big outdoor contracts currently held by tobacco companies. They won't be interested in taxis. It's the little people who will get hurt, again!"

A country town tobacconist claims the bill "means I'll have to refit my shop inside and out so people can't see any tobacco advertising." In fact all the typical tobacconist would have to do would be to peel off stuck on advertising from windows, remove cardboard advertisements from display areas, and perhaps paint over signs. Given that there was a phase out period of four years for this provision of the bill, the tobacconist's complaint 
suggested a level of indolence in interior decorating bordering on the comatose.

\section{Turning decent citizens into} common criminals

One day before the bill was due to be finally debated in the Lower House of Parliament, an advertisement was published headlined "Your local newsagent doesn't want to be made a common criminal by your local member." Pictured behind superimposed bars were a smiling, middle aged couple behind the counter of their (named) suburban newsagency. In quotation marks beneath the photograph, the couple told readers, "Newsagents are honest, hardworking small business people. The new Anti-Tobacco Bill will make it illegal to advertise, on the outside of our shop, which cigarette brands we sell. If there is even one cigarette sign outside we could be fined up to $\$ 5,000$ for the first offence, and then up to $\$ 10,000$ for a second offence. It we cannot pay we might face jail. Surely the Government and the Opposition have more important things to do than threaten our livelihoods with crippling penalties. They should spend more time in the

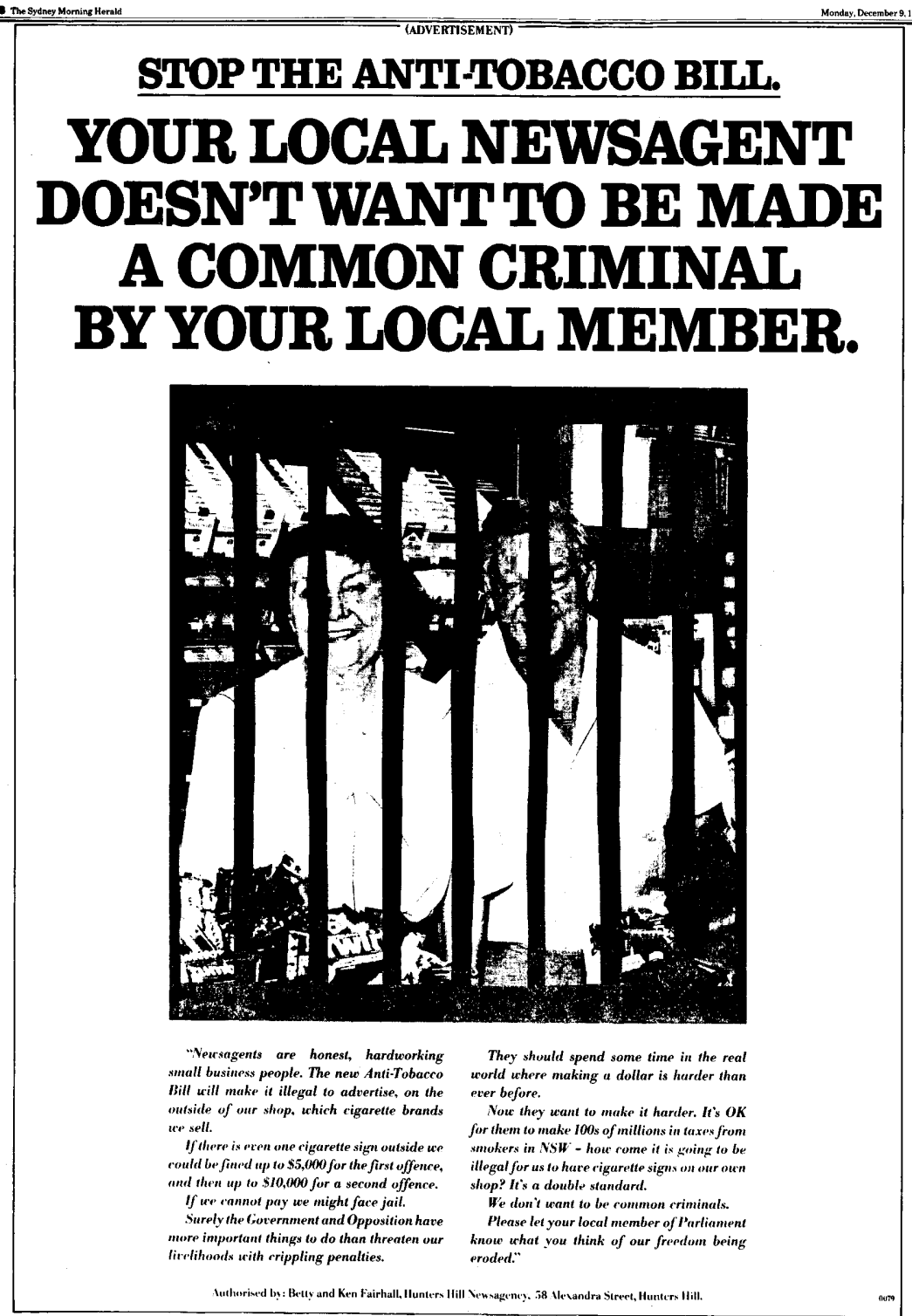

real world where making a dollar is harder than ever before. Now they want to make it harder. It's OK for them to make 100 s of millions in taxes from smokers in New South Wales - how come it is going to be illegal for us to have cigarette signs on our own shop? It's a double standard. We don't want to be common criminals. Please let your local member of Parliament know what you think of our freedom being eroded."

Like the earlier Don't kick us while we're down advertisement here was an attempt to show the face of ordinary Australians said to be affected by the bill. These were "your local newsagents," not anonymous workers in some obscure, dubious section of the tobacco industry. These people looked and sounded uncomplicated, decent, and law abiding. Here were archetypes of the very ordinariness and above all, reasonableness, that the industry wanted to portray as being behind those who wanted to retain tobacco advertising. As small business people, as distinct from giant corporations, they sought to represent the human face of the consequences of an allegedly ridiculous law. As they say, they are in the real world, the corollary of which is that anyone taking a different view is out of touch, a zealot, or a fanatic. Those supporting the bill were thus marginalised as a discrete movement: "Consider the views of those outside the antitobacco movement," urged one advertisement.

The central proposition of this advertisement - that decent, ordinary shopkeepers would be turned into criminals by the passage of the bill-implied that such shopkeepers would defy the law by continuing to display cigarette advertising. The sheer unlikelihood of this was of course not countenanced by the advertisement. There have been no overt instances of defiance of advertising bans on the radio, on television, or in the print media.

\section{Hypocrisy}

The accusation that there was rank hypocrisy involved in the government's collecting tobacco excise taxes while denying the right of sporting groups to accept sponsorship was another common theme. The country tobacconist who complained about his spurious shop refit argued, "Yet the Government will still collect the revenue on the cigarettes I sell. They don't seem to care if I can't find the money for the refit. So as the business dies, after years of building it up, I'll have to start putting off temporary staff and eventually loyal permanent staff. Our politicians should explain the true repercussions of this bill to these people."

The accusation of hypocrisy was countered in responses from the bill's protagonists by reference to tobacco use contributing to the costs of public health care for diseases caused by smoking, thereby seeking to deny that there was any moral equivalence between the government being allowed to take tobacco money, but sport being forbidden. But while the industry could lead with its accusations of hypocrisy in full page advertisements and through sympathetic media sports commenta- 


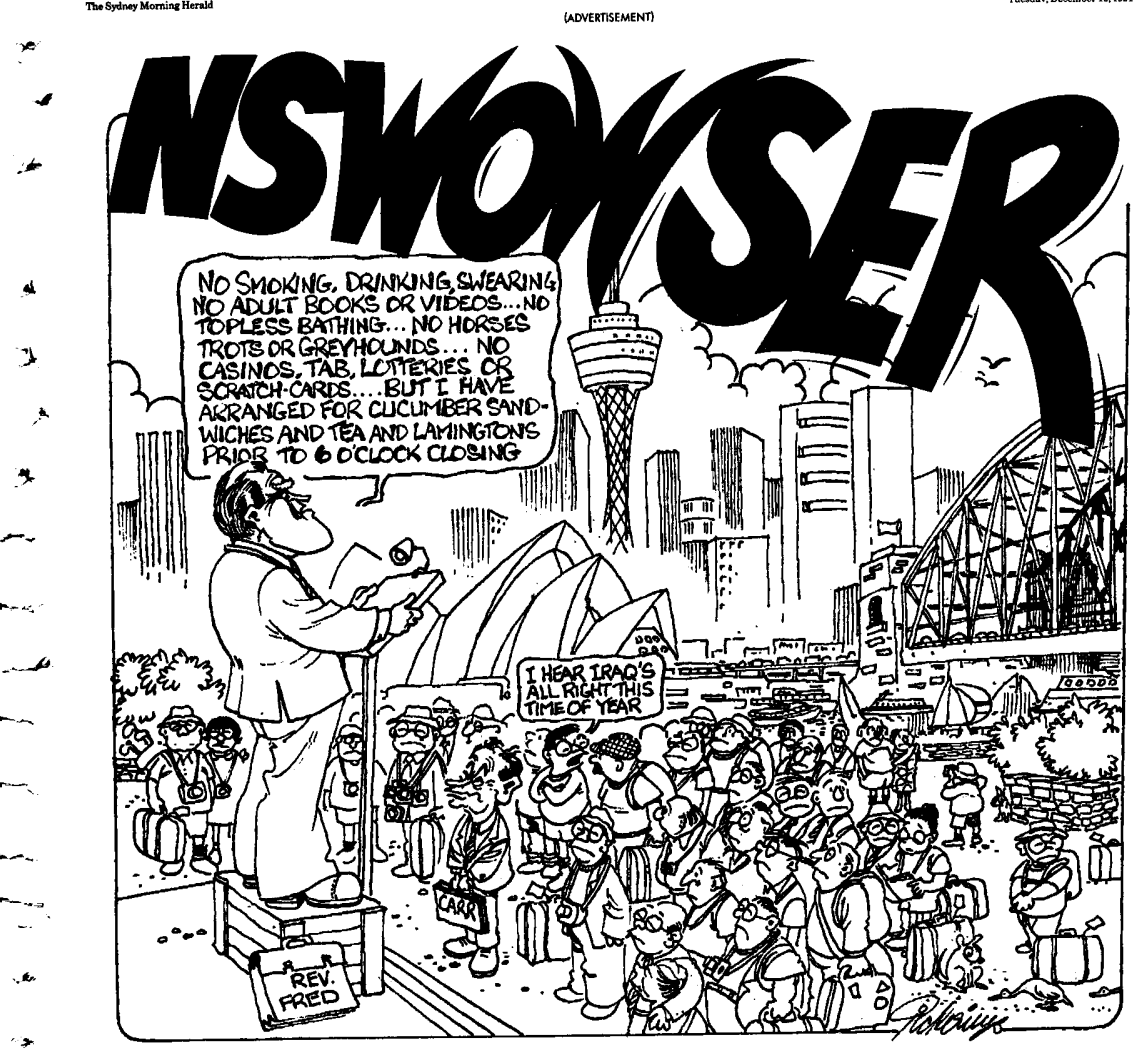

Is this the sort of NSW we want to live in?

Is this the freedom our parents and grandparents fought for? In the middle of our worst recession the Anti-Tobacco Bill puts at risk thousands of jobs in retailing, printing and distribution.

It will make common criminals out of any corner shopkeepers who choose to display on the outside of their shops what they sell inside. If the Bill is passed, it will make it illegal for sporting groups to freely choose their own sponsors.

We must let all politicians know we are adults and we want to do what we like when we like - within the law.

\section{ENOUGH IS ENOUGH!}

tors, the countervailing view could only be The Reverend Fred Nile, who introduced the bill, represents the Call to Australia Party, a that the bill was "the only anti-fag legislation would ever support."

oxygen to the flame of puritanismen sought to nurture in its characterisation of those seeking to restrict its activities. Nile provided his opponents with a set of gift wrapped negative appositions they sought to exploit in several advertisements, including a cartoon clearly designed to offend Nile which showed him naked in bed with a disconcerted Leader of the Opposition, suggesting that their political collusion on this issue had wider implications.

Wowser is a colloquial Australian term meaning a censorious person, a killjoy, ${ }^{4}$ and is commonly applied to anyone who seeks to suppress pleasure or fun. Historically, the term has been applied to the alcohol temperance movement, to those offended by public nudity or brief swimwear, and lately, to people concerned about smoking. A cartoon advertisement headed NSWowser showed Nile addressing a crowd with the words: "No smoking, drinking, swearing, no adult books or videos... no topless bathing ... no horses, trots or greyhounds... no casinos, TAB [licensed betting], lotteries or scratch-cards....But I have arranged for cucumber sandwiches and tea and lamingtons [an Australian cake popular with older people] prior to 6 o'oclock [bar] closing." The advertisement concluded, "is this the sort of NSW we want to live in?"

\section{Freedom to choose}

The New South Wales Rugby League, whose game is sponsored by the Winfield brand, ran an advertisement focusing on its right to choose any sponsor and describing this as almost a nationalistic duty: "As Australians we have a history of standing up for our rights. It's one of the great things that makes us Australian." Another continued in the same vein: "Is this the freedom our parents and grandparents fought for?"

An advertisement entitled The world according to Fred Nile (and all the other wowsers in the NSW parliament) sought to obfuscate the objectives of the bill, suggesting that Nile was attempting to ban smoking. Captioned against a series of cartoon characters it read: "I like to drive a car, I take the gamble. I like to over-eat, I take the gamble. I like to mountain-climb, I take the gamble. I like to race motor bikes, I take the gamble. I like to chase cars, I take the gamble" (a talking dog). The cartoon ended with Nile saying "I like to make choices for everyone else, and I don't agree with gambling!" It concluded, "We want the right to choose our own adult recreations" - as if sport or smoking itself were to be banned under the legislation.

Another stated that "If the Bill is passed, it will make it illegal for sporting groups to freely choose their own sponsors." Again, this was gross obfuscation: sporting groups would remain free to choose any sponsor, including a tobacco company, provided that the tobacco company was prepared to forgo the publicity that sponsorships traditionally entail. A host of large corporations were described in the press as likely to be interested in sponsoring the main tobacco sponsored sports such as cricket and rugby. 
One advertisement ambiguously suggested that the bill would ban sponsorship itself, rather than tobacco sponsorship. Its headline read that the bill "will ban the sponsorship of the Winfield Cup [rugby league] and horse races, B\&H World Series Cricket and Skiing, Peter Jackson motor racing, Rothmans bike racing and rugby union and the Philip Morris Arts Grant and Superband."

\section{Paternalism}

Related to the freedom issue was the theme of the proposed law and the political climate that spawned it as being paternalistic. "Australian adults are NOT children," argued one. "We must let all politicians know we are adults and we want to do what we like when we like within the law," said another. Though politicians are elected to represent the people and to enact legislative reform, this point seemed lost on the industry: "Fred Nile thinks he knows what is best for all of us," it argued, as if Nile had no business attempting to pursue his mandate.

\section{Surveys of public opinion}

The industry commissioned several surveys and published the results in advertisements with titles such as Listen to the people. The surveys were shamefully biased, with one starting with the question, "As a non-smoker do you think tobacco companies sponsoring sporting events, the arts and concerts is likely or unlikely to make you take up smoking?" With the predicability of day following night, $98 \%$ of respondents answered unlikely. By asking this question first, a response bias was introduced that influenced subsequent less loaded questions, all of which predictably went the industry's way.

Easily the most outrageous poll result followed an advertisement placed by the New South Wales Cricket Association entitled Don't let the lights go out on cricket. The advertisement invited readers to call a toll free phone number and register their opposition to the bill. Callers supporting the bill would not have their votes registered by this process. Yet in spite of this, an advertisement published three days later and authorised by the Tobacco Institute reported $90 \%$ of callers to be in favour and $10 \%$ to be against. When confronted with this apparent discrepancy by a television reporter the ensuing dialogue took place:

John Welch (Tobacco Institute): That was the result.

Interviewer: But they were only taking the "no" votes, you must have known that?

Welch: I did not have anything to do with that survey ... other than be advised of the result. Interviewer: But by running that statistic, you're misinforming the public. Would you concede that it might have been ill advised for you to run that figure?

Welch: I've told you, I don't concede anything. This is a battle and you never take a backward step.

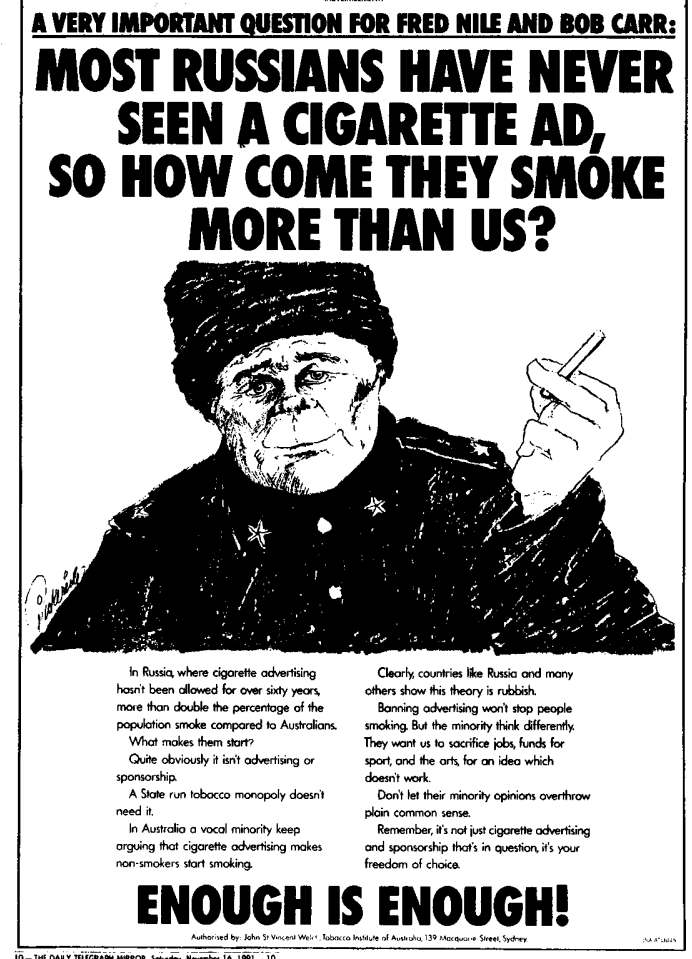

\section{No advertising in Russia}

An advertisement entitled Most Russians have never seen a cigarette ad, so how come they smoke more than us? explained to readers "In Russia, where cigarette advertising hasn't been allowed for over sixty years, more than double the percentage of the population smoke compared to Australians. What makes them start? Quite obviously it isn't advertising or sponsorship. A State run tobacco monopoly doesn't need it. In Australia a vocal minority keep arguing that cigarette advertising makes non-smokers start smoking. Clearly, countries like Russia and many others show this theory is rubbish."

Correspondents to newspapers replied that cigarettes are one of the few consumer goods readily available in the former Soviet Union; that they are extremely cheap; and that widespread health promotion campaigns do not exist. Still, the complexities of the arguments about the causal relation between advertising and consumption ${ }^{5}$ are almost certainly less resonant and persuasive to many people than the simplistic appeal of the argument put out by the industry.

\section{Discussion}

The industry's campaign failed to deter politicians from passing the bill, although a major amendment that was accepted (allowing sports with "national or international significance" to seek exemption from the phased out sponsorship ban from the government) means that this issue remains far from resolved in Australia. This exemption means that any New South Wales government sympathetic to the industry has the discretion to allow a high profile sport to continue its very public association with the industry. Federal (Labor) ministers for health and sport have already 
announced their intention to close this loophole through amendments to national broadcast legislation, which would override any state's actions in this area.

The political configuration that existed in New South Wales - a hung parliament with a majority supporting the bill-meant that the bill would inevitably pass, even without the support of the government, so it is interesting to speculate on why the industry spent the millions of dollars it did on the campaign.

The power of its starting arsenal was obvious: money and many grateful beneficiaries willing to do the industry's bidding. Being not permitted to advertise in the most expensive media (broadcasting and print), the industry has by default become a gargantuan advertiser outdoors and in shop fronts, providing expensive shop awnings, table umbrellas, and lucrative display incentives to small shopkeepers. Similarly in sport, its advertising reserves are such that it has been able to offer sponsorships at premium levels way above the market rates negotiated by other commercial sponsors. If an oil company and a car company (which have other direct advertising options) were competitively negotiating sponsorship with a sport around a figure of, say, \$A 2 million, tobacco companies in Australia could offer unparalleled higher sums. For example, in 1988 the Winfield Rugby League sponsorship in New South Wales was worth only $\$$ A 1.1 million. By 1990 , and despite a recessionary environment, this had risen to $\$ \mathrm{~A} 8$ million, ${ }^{6}$ way ahead of estimates for other sponsored sports. Anticipating the advance of further advertising restrictions, the industry has poured rivers of money into sponsorship of sporting events to a point where most sporting administrators see the prospect of alternative, lesser sponsorships as comparative penury.

Thus, beyond its traditional support base of direct beneficiaries (tobacco growers, tobacco workers, and some advertising agencies) the industry has been able to mesmerise some other important constituencies with its artificially high funds. Partial advertising bans in Australia have in this way had the untoward effect of artificially strengthening the bond between the industry and those who are legally still able to promote cigarettes. The emoluments and fringe benefits of sponsorship so vividly documented by Peter Taylor ${ }^{7}$ create a dependency among beneficiaries who understandably don't want to kill the goose that lays the golden egg for the sake of what they hope they can portray as a muddleheaded and dubious appeal to public health.

Presumably, the industry had great confidence in the power of its sheer financial clout and in the weight of numbers among its grateful new constituents in small business and sport. The rugby league, for example, threatened to campaign among its hundreds of thousands of working class, traditionally Labor voting club members, for a political vote against the Opposition Labor Party at the next election. ${ }^{8}$ When the government supported the bill this threat became even more lame, with voters having no one now to offer their vote.
The themes I have described above were nearly all linked to the consequences that would befall such ordinary Australians going about the pursuit of their incomes and sports. While the proponents of the bill attempted to frame the meaning of the bill in terms of public health and the protection of children, the industry almost completely avoided these issues and instead reframed the issues it judged as serving its interests in the ways I have described.

The most important question that remains is whether, had political support for the bill been more tenuous, the industry's efforts would have overcome. Attempts to answer this question in this instance must remain speculative, but the subject represents a very neglected field of research in tobacco control. Massive propaganda offensives by the tobacco industry have the potential to undermine both efforts to achieve important legislative reforms in tobacco control and advances in public opinion conducive to reducing smoking. Yet as an area for serious research, analysis, and strategic development, it remains mysteriously marginalised in professional published work on tobacco control.

In speaking among my colleagues in Australia, the dominant and most animated discussions seemed to be occupied with the shoddy logic and argumentative ineptitude of the industry's campaign. Many point scoring letters were written to the press by such people, pointing out the folly involved and attempting ridicule. Such preoccupations, however many, may be beside the point. Political battles are only seldom won on the elegance of logic or by those who can best assemble rational arguments. These are mere strategies within a wider battle front. The real issue is which overall framings of debates best succeed in capturing public opinion and political will.

I look forward to reading analytical work on such matters in future issues of Tobacco Control.

The role of Stephen Woodward, Executive Director of Action on Smoking and Health (ASH) was vital throughout the passage of the bill. Stephen drafted the bill for the Reverend Nile and worked closely with politicians from all parties who spoke during the parliamentary debate. His office initiated several letter writing campaigns, which resulted in thousands of supportive letters being sent to politicians. Among these was a joint initiative with the Public Health Association, which coordinated a strongly worded letter signed by 56 professors of medicine being sent to every politician in New South Wales. His shepherding of several wavering politicians through the often vicious onslaughts of parliamentary and media debate was, by consensus of most involved in smoking control in New
South Wales, considered masterly.

1 Steketee $M$, Coultan $M$. Court decision may have Greiner biting his bullets. Sydney Morning Herald 1991 Dec 11:4. 2 Garcia LM. Tobacco: Greiner caves in on bans. Sydney Morning Herald 1991 Nov 20:1.

3 Macken L. Gays join Nile by backing "anti-fags" bill. Sydney Morning Herald 1991 Nov 9:9.

4 Wilkes GA. A dictionary of Australian colloquialisms. Sydney: Sydney University Press, 1985.

5 Chapman, $S$. On the limitations of econometric analysis in cigarette advertising studies. $\mathrm{Br} \mathcal{J}$ Addict 1989; 84:1267-77.

6 Williams D. Winfield worth more than $\$ 8$ million to League. Sydney Morning Herald 1991 Nov 19:3.

7 Taylor P. The smoke ring: the politics of tobacco. London: Bodley Head, 1985

8 Deegan $L$, Thorpe $D$. RL bosses challenge Carr over smoke bill. Sunday Telegraph 1991 Nov 17. 
Translations

of abstract
Profil d'une campagne: la tentative de faire échouer la loi de 1991 interdisant la publicité pour le tabac dans l'état de New South Wales (Australie)

Simon Chapman

Résumé

Vers la fin de l'année 1991, l'industrie de tabac australienne a lancé une importante campagne de publicité pour essayer de dissuader les politiciens de New South Wales d'adopter la loi de 1991 sur l'interdiction de la publicité pour les produits du tabac. Cette loi prévoyait d'interdire toute publicité pour le tabac, y compris le parrainage de manifestations sportives.

Les thèmes et les arguments utilisés par l'industrie du tabac à l'appui de leur opposition sont présentés. Ils portent par exemple sur la perte d'emplois, les difficultés financières pour les "couches sociales inférieures" durant la récession, le "culpabilisation" d'honnêtes ouvriers, l'hypocrisie, le néo-puritanisme, la liberté de choix, le paternalisme, l'opposition du public, et l'absence de publicité en Russie.

Le choix de ces thèmes et les moyens utilisés par les représentants d'organisations de promotion de la santé pour les contrer sont présentés.
Anatomía de una campaña: Intento de derrotar la Ley sobre Prohibición de Publicidad del Cigarrillo aprobada en 1991 en Nueva Gales del Sur (Australia) Simon Chapman

\section{Resumen}

A finales de 1991, la industria australiana del tabaco lanzó una campaña masiva de publicidad en un intento por disuadir a los políticos del estado de Nueva Gales del Sur de aprobar la ley de 1991 sobre Prohibición de la Publicidad de Tabaco. El propósito de dicha ley era el de eliminar todas las formas de publicidad de tabaco en Nueva Gales del Sur, incluyendo la bublicidad dada a los cigarrillos durante el patrocinio de activadades deportivas. Se describen los temas y los medios empleados para enmarcar la oposición de la industria. Estos temas incluyen trabajos perdidos; tiempos dificiles para la "persona que fuma" durante la recesión; cómo se hace sentir a los trabajadores honestos como delincuentes; hipocresía; neo-puritanismo; la libertad de elección; paternalismo; la oposición del público; y la ausencia de publicidad en Rusia. Se discute la elección de estos temas y los intentos de contrarrestarlos por parte de los trabajadores de salud.

\section{烟草商企图阻止新南威尔士烟草广告禁止法案的通过}

\section{理查德・戴纳德}

1991 年底, 利亚烟草工业发起了大规模的广告宣传, 以试图说服新南成尔士州的政 府官员反对烟草广告限制法案的通过, 该法案的目的在于经终结束目前在新南威尔士尚存的 各种烟草广告形式，包括通过举助体育比赛向公众作烟草广告. 本文描述了烟草工业经常用 于陷寞反吸烟人士及团体的各种议题及手段，包括失业、在经济衰退期间平民生活的艰难、 正自工人数判有㭌、虚伪、新清数徒主义、选择的自由、大男子主义、公众的反对和伐罗斯 无广告等种种问题. 本文讨论了烟草界这些议题的选择及医务工作者对此进行反击的种种努 力. 